\title{
Kenya: Islamic scholars find no religious justification for FGM/C
}

Population Council

Follow this and additional works at: https://knowledgecommons.popcouncil.org/departments_sbsr-rh

Part of the Demography, Population, and Ecology Commons, Family, Life Course, and Society Commons, Gender and Sexuality Commons, International Public Health Commons, Medicine and Health Commons, Sociology of Culture Commons, and the Sociology of Religion Commons How does access to this work benefit you? Let us know!

\section{Recommended Citation}

"Kenya: Islamic scholars find no religious justification for FGM/C," FRONTIERS OR Summary. Washington, DC: Population Council, 2008. 
Kenya

FGM/C

OR Summary 73

\section{Islamic Scholars Find No Religious Justification for FGM/C}

Following a series of discussions on Islam and FGM/C with religious leaders in Kenya's Somali-dominated North East Province, scholars agreed that infibulation should end, but did not achieve consensus on other aspects of FGM/C. Continuing steps include mobilizing Imams as community advocates against FGM/C and engaging communities in group discussions about justifications for continuing the practice.

\section{Background}

In 2004 FRONTIERS undertook a diagnostic study on the cultural basis of female genital mutilation and cutting $(\mathrm{FGM} / \mathrm{C})$ in Kenya's Somali community. The study showed universal support for $\mathrm{FGM} / \mathrm{C}$, and indicated that one of the major justifications for the practice is the perception in the community that Islam requires female as well as male genital cutting, and that non-circumcised women cannot be good Muslims (other justifications are custom, tradition, control of women's sexual desire, and preservation of virginity). Interviews with informants showed that belief in the religious justification overrides arguments about the health and human rights aspects and the knowledge that it is illegal in Kenya.

In 2005 the FRONTIERS Program, in collaboration with UNICEF, launched an intervention to engage the community in discussions about FGM/ $\mathrm{C}$ in order to clarify the religious position on FGM/C. The diagnostic study had indicated that removing the religious justification for FGM/C would greatly reduce community support for the practice.

To support discussions on FGM/C and Islam, FRONTIERS arranged four symposia in Wajir district. The symposia involved a total of 44 degree-holding, Arabic-speaking Islamic scholars (all Somali, and also including some female scholars) . Medical experts explained and illustrated the process and possible complications of
FGM/C, and traditional circumcisers and women who had undergone FGM/C described their experiences to the scholars, many of whom had little understanding of the practice. With UNICEF, FRONTIERS organized a regional symposium, held in the provincial capital, Garissa, attended by 25 Kenyan and one Saudi Arabian scholar. FRONTIERS also held a national symposium for religious leaders with UNICEF, UNFPA and GTZ in Mombassa, attended by 55 Somali and non-Somali scholars and a visiting scholar from Sudan. Facilitators - themselves non-Somali Islamic scholars-led discussions on the place of FGM/C in Islamic teaching in terms of Shariah (Islamic) law, shared their views on the underlying reasons for practicing $\mathrm{FGM} / \mathrm{C}$, and discussed next steps for engaging communities in dialogue on the practice.

Teachings of Islam relevant to FGM/C:

- No verse of the Quran, or deeds or sayings of the Prophet, support FGM/C, and there is no consensus among Muslim jurists on the practice. While male circumcision is strongly supported by Shariah law, there can be no analogy between male cutting (the foreskin) and female cutting (functional organs).

- Islam offers many positive messages with relevance to discontinuing $\mathrm{FGM} / \mathrm{C}$. Islam prohibits cutting healthy organs or causing physical harm, 
and urges Muslims to keep themselves hygienic for "clean" worship, which can be compromised if a woman is infibulated.

- Islam directs believers to take advice from experts, including doctors. Medical experts at the symposia confirmed that cutting interferes with women's sexual response and thus violates their right to pleasure.

- Medical experts emphasized that sexual desires and behavior are generated in the brain, not the sexual organs. Thus, FGM/C does not control women's sexuality as commonly believed; instead, participants were reminded that Islam emphasizes a good upbringing (tarbiya) as the best guidance against immorality.

- Though scholars agreed that no religious requirement for $\mathrm{FGM} / \mathrm{C}$ exists, and that infibulation, its most extreme form, should be abandoned, most were still reluctant to publicly declare their opposition to the practice. However, the fact that the scholars discussed abandonment of the practice indicates their acceptance that FGM/C has no religious basis - as a religious act cannot be abandoned under Islamic law.

- Barriers to working with religious scholars included reticence about openly discussing sexuality and the belief that FGM/C is a woman's issue, and thus a low-priority topic. Also, poor understanding of Arabic terms has led to misunderstanding and misinterpretation of Islamic texts. FRONTIERS has produced a set of resource materials that can be used during discussions to provide accurate versions of relevant Islamic texts.
- The presence of female scholars added much value to the debate, from both an Islamic and women's perspective. Male scholars were impressed that Somali women could voice their opinions so clearly and were strongly opposed to $\mathrm{FGM} / \mathrm{C}$, because they believed that all women favored the practice. Overall the intervention was a unique opportunity to fully inform male scholars about a practice that had not been openly discussed previously.

\section{Next Steps}

- FRONTIERS is continuing to work with Islamic scholars and Imams, to help them become advocates for change and to hasten the move toward a total ban on FGM/C.

- To complement the work with the Imams, education and dialogue with other community groups, drawing support from religious leaders, health workers, and government officials, and provincial and national seminars to develop support from other Islamic communities, is also continuing.

\section{Programmatic Recommendations}

- It is vital to fully understand the local rationale for FGM/C, engage carefully with Islamic leaders to avoid a backlash, and use a range of religious arguments that demonstrate how the practice runs counter to many Islamic principles. Change is likely to be slow, requiring a long commitment, and it is preferable to persuade a few leaders and work with them to convince the majority, and to work with various stakeholders.

Sheikh Abdi, Maryam. 2007. "A religious oriented approach to addressing FGM/C/C among the Somali community of Wajir, Kenya," FRONTIERS Report. Nairobi: Population Council. See Also: Jaldesa, Guyo W., Ian Askew, Carolyne Njue, and Monica Wanjiru. 2005. "Female genital cutting among the Somali of Kenya and management of its complications," FRONTIERS Final Report. Washington, DC: Population Council. Available on our website at www.popcouncil.org/frontiers or by e-mail: frontiers@popcouncil.org

This publication is made possible by the generous support of the American people through the United States Agency for International Development (USAID) under the terms of Cooperative Agreement No. HRN-A-00-98-00012-00. The contents are the responsibility of the FRONTIERS Program and do not necessarily reflect the views of USAID or the United States Government. 